\title{
Cutaneous Melanoma Pathologic Distant Metastasis TNM Finding v8
}

National Cancer Institute

\section{Source}

National Cancer Institute. Cutaneous Melanoma Pathologic Distant Metastasis TNM

Finding v8. NCI Thesaurus. Code C136922.

A pathologic finding about one or more characteristics of cutaneous melanoma,

following the rules of the TNM AJCC V8 classification system as they pertain to distant metastases. 